\title{
Status of the black-legged kittiwake (Rissa tridactyla) breeding population in Greenland, 2008
}

\author{
Aili Lage Labansen, ${ }^{1}$ Flemming Merkel, ${ }^{2}$ David Boertmann ${ }^{2}$ \& Jens Nyeland ${ }^{3}$ \\ 1 Greenland Institute of Natural Resources, PO Box 570, DK-3900 Nuuk, Greenland \\ 2 National Environmental Research Institute, Department of Arctic Environment, Aarhus University, Frederiksborgvej 399 , DK-4000 Roskilde, Denmark \\ 3 Naturama, Dronningmaen 30, DK-5700 Svendborg, Denmark
}

\section{Keywords}

Black-legged kittiwake; Greenland; population status; Rissa tridactyla.

\section{Correspondence}

Aili Lage Labansen, Greenland Institute of Natural Resources, PO Box 570, DK-3900 Nuuk, Greenland. E-mail: aili@natur.gl

doi:10.1111/j.1751-8369.2010.00169.x

\begin{abstract}
Based on the intensified survey efforts (since 2003) of Greenlandic breeding colonies of black-legged kittiwake (Rissa tridactyla), the total Greenland breeding population was estimated at roughly 110000 breeding pairs, constituting about $4 \%$ of the total North Atlantic breeding population. This population estimate of black-legged kittiwake is the most reliable and updated estimate hitherto reported for Greenland. The results confirm considerable population declines in many areas of West Greenland. The breeding population of blacklegged kittiwakes in the Qaanaaq area appears healthy, whereas the rest of the west coast has experienced declines, especially the north-western region (in the area from Upernavik to Kangaatsiaq). Exactly when these reductions have occurred is uncertain because of the limited survey effort in the past, but some colonies declined as far back as the mid-1900s, whereas declines of other colonies have occurred since the 1970-80s. East Greenland data from the past are few, but recent aerial surveys confirm that the abundance of breeding kittiwakes on this inaccessible coast is low. The reasons for the West Greenland declines are not documented. Poor feeding conditions and a high hunting pressure, particularly prior to 2002 when the open season was shortened considerably, are possible explanations.
\end{abstract}

The black-legged kittiwake Rissa tridactyla (hereafter kittiwake) is a widely distributed seabird in the circumpolar Arctic (Cramp \& Simmons 1983; Hatch et al. 1993), numbering more than 5 million pairs when all national population estimates are summed (Cramp \& Simmons 1983; Hatch et al. 1993; Anker-Nilssen et al. 2000; Mitchell et al. 2004; Bakken et al. 2006; Hatch et al. 2008; Barrett et al. 2006). Reports on declines in breeding populations, poor breeding performance and so on, from many regions of the breeding range of kittiwakes, have led to an increased international focus on this species (Regehr \& Montevecchi 1997; Carscadden et al. 2002; Frederiksen et al. 2004; Mitchell et al. 2004; Barrett et al. 2006; Bornaechea \& Gardarsson 2006; Gardarsson 2006; Mavor et al. 2006; Sunnanå \& Fossheim 2008). Hence, the kittiwake is now considered to be a species of conservation concern by the Arctic Council working group Conservation of Arctic Flora and Fauna (CAFF), and the need for a circumpolar conservation strategy and action plan is being considered by CAFF's Seabird Expert Group.
The kittiwake is categorized as vulnerable (VU) on the Greenland Red List (Boertmann 2007).

The kittiwake is a widespread breeder in Greenland, particularly along the west coast. Former estimates of the West Greenland breeding population have been somewhere between 80000 and 200000 pairs (Boertmann et al. 1996; Bakken et al. 2006), based largely on outdated surveys (as old as 80 years) of varying quality, and the East Greenland population has been virtually unknown.

As the kittiwake is subject to hunting in Greenland, in contrast to elsewhere in the North Atlantic (Merkel \& Barry 2008), an updated and more reliable estimate of the breeding population is required for management purposes. This was underlined by Nyeland (2004), who documented a general decreasing trend in the breeding population in West Greenland during the past century. Therefore, the survey effort of the Greenland kittiwake breeding population was intensified after 2003 with the aim of surveying all significant breeding areas within a 
reasonably short time frame. The results from these surveys have been published in regional reports (Boertmann 2004, 2006; Nyeland \& Mathæussen 2004; Burnham et al. 2005; Merkel et al. 2007; Nyeland 2007), and in combination with unpublished results from other surveys, allow us to make an updated estimate of the breeding population in Greenland. The objective of this study is to present an updated population estimate of breeding kittiwakes in Greenland. Key breeding areas are identified and apparent population trends are discussed.

\section{Methods}

Data on kittiwake breeding numbers are stored in a database containing information about Greenland's seabird colonies, which is maintained by the National Environmental Research Institute and is available on the institute's website (Boertmann et al. 1996; Bakken et al. 2006). This database includes historical kittiwake data (breeding location data back to 1898) as well as all survey results from recent years (e.g., Boertmann et al. 1996; Boertmann 2006; Merkel et al. 2007). The database contains information on colony location and survey results for all colonial seabird species breeding in Greenland (Boertmann et al. 1996; Bakken et al. 2006).

From this database the most recent survey results (2007 was the most recent survey year in West Greenland; 2008 in East Greenland) from all known kittiwake colonies in Greenland were extracted. These data are expressed either as the number of individuals or nests/ pairs. Nest/pairs are here presented as "apparently occupied nests" (AONs), and numbers of individuals were converted to number of AONs by using a K-factor of 0.65. This was derived from a study in Qaanaaq (Merkel et al. 2007), which, as a result of the lack of data from other regions, was applied to the entire area. Survey data in the database are categorized as being of high, medium or low quality. Colonies are spatially grouped according to administrative municipalities, which are named after the largest town. For the purpose of this presentation the West Greenland data were further grouped into four larger regions (north, north-west, south-west and south), and the East Greenland data were grouped into two regions (north-east and south-east), as shown in Fig. 1.

All survey results in the West Greenland data set were obtained by direct counts on site (primarily from a boat using binoculars), except for two colonies in Ilulissat, two in Upernavik and the four colonies in the Qaanaaq area, which were all photographed systematically, and AONs were counted from these photographs (Boertmann 2006; Merkel et al. 2007; Nyeland 2007). Colony surveys were mainly carried out in July $(96 \%$ of the West Greenland surveys), which is the time when at least one of the adults or large chicks are present on their nests. A few colonies were surveyed in late June $(n=7)$, in August $(n=3)$ and in very early September $(n=1)$ (see the Appendix).

East Greenland data were treated separately. In JuneJuly 2008, an aerial seabird survey was conducted along the entire coast from Kap Farvel $\left(60^{\circ} \mathrm{N}\right)$ to Kap Morris Jesup $\left(83.5^{\circ} \mathrm{N}\right)$, and this contributed significantly to the otherwise limited data for this part of Greenland (Boertmann et al. 2009; Merkel et al. 2010).

\section{Results}

\section{West Greenland}

Sixteen West Greenland kittiwake colonies in the database may never have existed, and were excluded from the data set. The remaining 246 colonies, accepted to have been occupied at some time in West Greenland since 1920, were included in the present summary (see the Appendix; Fig. 1). The median year of the most recent count of these colonies was 2003 (standard deviation $=6.7$ years); of the 246 colonies, $64.6 \%$ had been visited since 2003 and $92.3 \%$ within the past 10 years (1998-2007) (Table 1). The remaining 19 colonies (with most recent survey data of more than 10 years old) were all small ( $\leq 65$ AONs) or empty. The oldest count included in the present summary is from 1954 (see the Appendix; Table 1).

Among the 246 colonies, 139 were occupied by breeding pairs during the most recent visit, and their numbers add up to a total West Greenland breeding population of 103348 AONs (Fig. 1; Table 2). As much as $95.8 \%$ of the total number of AONs were counted in 2003 or later, and $99.7 \%$ in 1998 or later (Table 1). The mean colony size was 744 AONs, with a range from 1 to 18707 . The median colony size was 57 AONs, and only three colonies had more than 10000 AONs (Fig. 1).

Data from 12 colonies were converted from number of individuals to AONs, and added up to 3588 AONs (3.5\% of the total number of AONs). The quality of the count data were categorized as high, medium and low for 94, 20 and nine colonies, respectively. For 16 colonies the quality of the count data was not reported (see the Appendix). Low-quality count data accounted for $0.3 \%$ of the total number of AONs. Count data of medium and high quality accounted for $98.4 \%$ of the total number of AONs.

Figure 1 and Table 2 give an overview of the regional distribution and abundance in West Greenland. The northern region is characterized by very few but large colonies, holding $34.5 \%$ of the West Greenland breeding population in only four colonies. Colonies are far more abundant in the north-west region, from Upernavik in the north to Kangaatsiaq in the south, being home to $71.1 \%$ of all registered colonies, although they house 


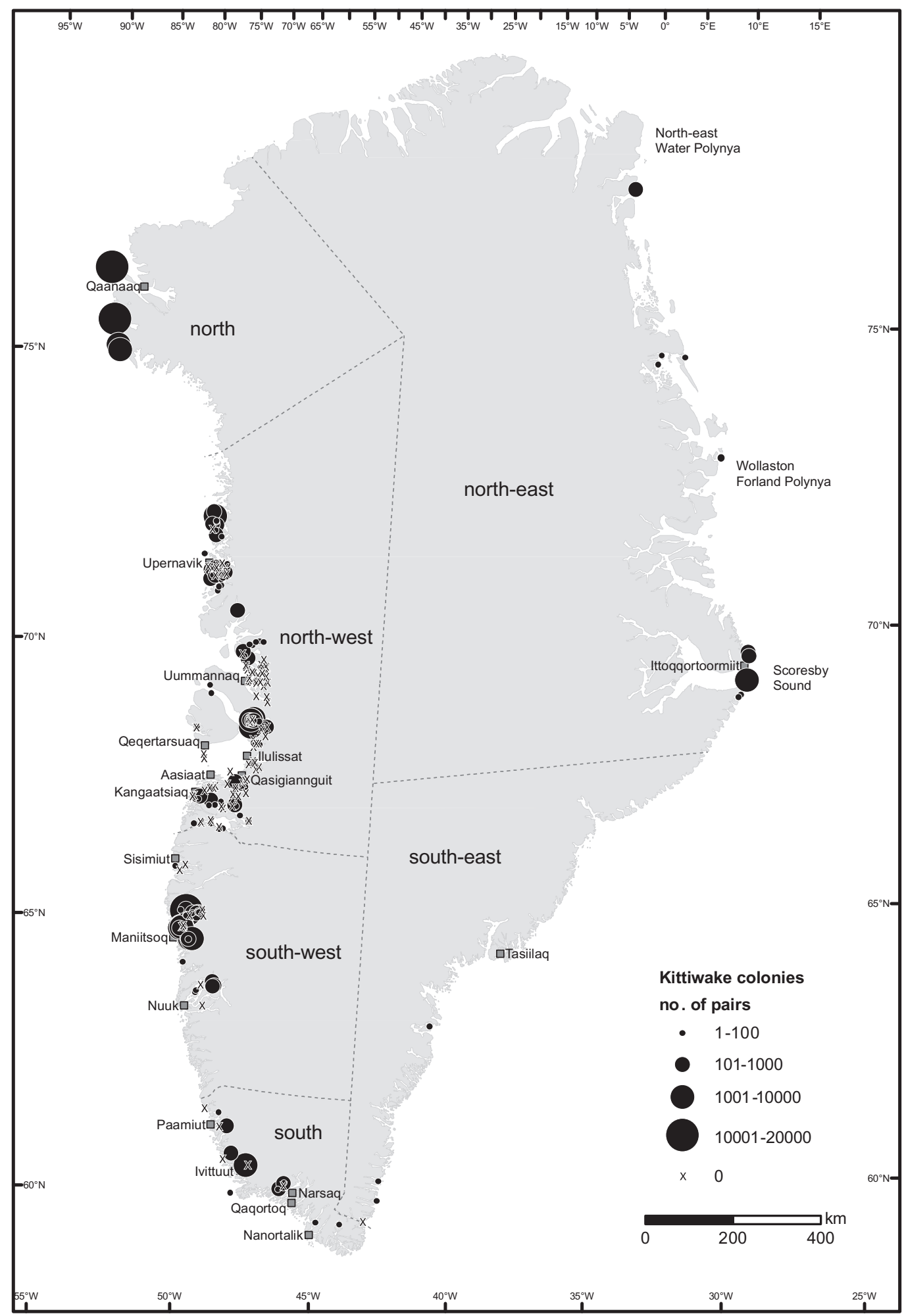

Fig. 1 Map of Greenland with locations of the largest town from each municipality (marked as squares), and locations of all 246 registered breeding colonies in West Greenland and 16 registered breeding colonies in East Greenland. The size of the colonies at the most recent visit (with 2007 being the most recent survey year in West Greenland and 2008 in East Greenland) is indicated by the size of the circle. Empty colonies are marked with an X. The borders between the four regions in West Greenland (north, north-west, south-west and south) and the two regions in East Greenland (north-east and south-east) are indicated with dotted lines. 
Table 1 Distribution of the number $(N)$ of kittiwake colonies and number of apparently occupied nests (AONs) by the most recent survey year in West Greenland.

\begin{tabular}{lrrrrrr}
\hline & & & & & \multicolumn{2}{c}{ Cumulative } \\
\cline { 6 - 7 } Year & $N_{\text {colonies }}$ & $N_{\text {AONs }}$ & $N_{\text {colonies }}(\%)$ & $N_{\text {AONS }}(\%)$ & $N_{\text {colonies }}(\%)$ & $N_{\text {AONs }}(\%)$ \\
\hline 2007 & 28 & 4884 & 11.4 & 4.7 & 11.4 & 4.7 \\
2006 & 10 & 35746 & 4.1 & 34.6 & 15.4 & 39.3 \\
2005 & 74 & 23301 & 30.1 & 22.5 & 45.5 & 61.9 \\
2004 & 1 & 0 & 0.4 & 0.0 & 45.9 & 61.9 \\
2003 & 46 & 35025 & 18.7 & 33.9 & 64.6 & 95.8 \\
2002 & 2 & 2623 & 0.8 & 2.5 & 65.4 & 98.3 \\
2001 & 3 & 10 & 1.2 & 0.0 & 66.7 & 98.3 \\
2000 & 40 & 732 & 16.3 & 0.7 & 82.9 & 99.0 \\
1999 & 6 & 301 & 2.4 & 0.3 & 85.4 & 99.3 \\
1998 & 17 & 514 & 6.9 & 0.5 & 92.3 & 99.8 \\
$1988-97$ & 8 & 121 & 3.3 & 0.1 & 95.5 & 99.9 \\
$1978-87$ & 2 & 50 & 0.8 & 0.0 & 96.3 & 100.0 \\
$1968-77$ & 8 & 0 & 3.3 & 0.0 & 99.6 & 100.0 \\
$1958-67$ & & & & & & \\
$1948-57$ & 1 & 41 & 0.4 & 0.0 & 100.0 & 100.0 \\
Total & 246 & 103348 & & & & \\
\hline
\end{tabular}

Table 2 Number of kittiwake colonies, number of colonies occupied by breeders and number of apparently occupied nests (AONs) at the most recent survey (with 2007 being the most recent survey year in West Greenland and 2008 in East Greenland) within each region in Greenland. The regions in West Greenland are divided further into municipalities.

\begin{tabular}{|c|c|c|c|c|}
\hline \multirow[b]{2}{*}{ Region } & \multirow[b]{2}{*}{ Municipality } & \multicolumn{2}{|c|}{ Number of colonies } & \multirow{2}{*}{$\begin{array}{l}\text { Number } \\
\text { of AONs }\end{array}$} \\
\hline & & Total & Occupied & \\
\hline North & Qaanaaq & 4 & 4 & 35666 \\
\hline \multirow[t]{7}{*}{ North-west } & Upernavik & 42 & 32 & 6230 \\
\hline & Uummannaq & 39 & 12 & 732 \\
\hline & Qeqertarsuaq & 6 & 2 & 75 \\
\hline & Ilulissat & 40 & 17 & 22034 \\
\hline & Qasigiannguit & 12 & 5 & 323 \\
\hline & Aasiaat & 1 & 0 & 0 \\
\hline & Kangaatsiaq & 35 & 17 & 1065 \\
\hline \multicolumn{2}{|c|}{ Subtotal north-west } & 175 & 85 & 28376 \\
\hline \multirow[t]{3}{*}{ South-west } & Sisimiut & 5 & 1 & 50 \\
\hline & Maniitsoq & 35 & 29 & 32421 \\
\hline & Nuuk & 7 & 5 & 905 \\
\hline \multicolumn{2}{|c|}{ Subtotal south-west } & 47 & 35 & 33376 \\
\hline \multirow[t]{4}{*}{ South } & Paamiut & 8 & 4 & 3295 \\
\hline & Qaqortoq & 3 & 3 & 188 \\
\hline & Narsaq & 5 & 4 & 299 \\
\hline & Nanortalik & 4 & 4 & 65 \\
\hline \multicolumn{2}{|c|}{ Subtotal south } & 20 & 15 & 3847 \\
\hline \multicolumn{2}{|c|}{ West Greenland total } & 246 & 139 & 103348 \\
\hline \multicolumn{2}{|c|}{ North-east } & 12 & 12 & 3537 \\
\hline \multicolumn{2}{|l|}{ South-east } & 4 & 3 & ca. 200 \\
\hline \multicolumn{2}{|l|}{ TOTAL } & 262 & 155 & 107085 \\
\hline
\end{tabular}

only $29.5 \%$ of the breeding population. The south-west region (from Sisimiut to Nuuk) holds $19.1 \%$ of all the colonies, and $32.3 \%$ of the total breeding population. The smallest numbers of kittiwakes were found in the southern region (from Paamiut to Nanortalik), with $8.1 \%$ of the colonies and $3.7 \%$ of the breeding population (Table 2).

Of the 246 West Greenland colonies included in the data set, 107 (43\%) were abandoned at the latest survey. Only in Qaanaaq were no colonies abandoned, whereas $51 \%$ were abandoned in the north-west, $26 \%$ in the south-west and $25 \%$ in the southern Greenland region (Table 2).

Looking at the smaller regions, the municipalities, the largest numbers of breeding kittiwakes occur in Qaanaaq, Maniitsoq and Ilulissat, with 34.5, 31.4 and 21.3\%, respectively, of the total West Greenland population. The remaining municipalities hold between 0 and $6 \%$ of the breeding population (Fig. 1; Table 2). The municipalities with the largest numbers of empty kittiwake colonies during the most recent survey were Uummannaq (27 of 39), Kangaatsiaq (25 of 35) and Ilulissat (17 of 40) (Table 2).

\section{East Greenland}

Only 16 breeding colonies or possible breeding colonies are recorded from East Greenland (see the Appendix; Fig. 1). Four are in the region between $60^{\circ}$ and $69^{\circ} \mathrm{N}$ (in the south-east region), and 12 are found north of $69^{\circ} \mathrm{N}$ (in the north-east region). Nine colonies were surveyed in 2008, of which three were new and one abandoned. One new colony was recorded in north-east and two new colonies were recorded in south-east Greenland, although the name of one of the latter colonies indicates that the site has previously been occupied by kittiwakes 
(see the Appendix). Five colonies north of $69^{\circ} \mathrm{N}$ were surveyed in 2003-04 by Gilg (2005) (in two of these kittiwakes were present, but breeding was not confirmed), and the remaining two colonies have not been surveyed since 1993 and 1933, respectively. The colonies in East Greenland are relatively small (maximum 1300 AONs), and the sum of the latest counts adds up to less than 4000 AONs (Table 2).

\section{Discussion}

\section{Numbers}

The results of recent kittiwake surveys have improved our knowledge on the status and distribution of the breeding population of kittiwakes in Greenland considerably. Given the large distribution range and the often remote locations of the breeding colonies, the presented population estimate of nearly 110000 pairs must be considered as a good estimate. The total estimate is within the range of former estimates, but has now been updated and much better documented (Boertmann et al. 1996; Bakken et al. 2006).

Population estimates based on surveys distributed over time suffer from some sources of error. One is interannual variation in attendance at breeding colonies (Hatch $\delta$ Hatch 1988; Baird 1990). However, considering the large number of colonies counted within a relatively short time frame, a balance between unusually high or low colony attendances in the survey year is expected. Another factor is the possibility that some of the colonies found with few or no breeding pairs more than 10 years ago may have changed status. Yet, large increases in colony size are unlikely to stay unnoticed in West Greenland, where local people frequently travel along the coasts and are very aware of the presence of seabird colonies. As the majority of the kittiwake data were collected as AONs in July, before the fledging period (when prospecting immature birds may occupy empty nests), the population estimates are not highly sensitive to variation in daily or seasonal attendance (Boulinier et al. 1996; Cadiou \& Monnat 1996). Count data of kittiwakes are most commonly given in AONs (e.g., Mitchell et al. 2004; Barrett et al. 2006), and the K-factor used to convert from the number of individuals to AONs may not be representative for all of Greenland. However, as most count data were collected as AONs $(96.5 \%)$, this error is small. The small contribution of data categorized as being of low quality is similarly considered a minor source of error $(0.4 \%$ of the total number of AONs). The fact that all the largest colonies and the areas with high densities of registered colonies were covered in the more recent surveys should secure a good estimate for the population status in West Greenland.
The present estimate of the Greenland breeding population constitutes about $3.8 \%$ of the North Atlantic kittiwake population (Cramp \& Simmons 1983; AnkerNilssen et al. 2000; Mitchell et al. 2004; Bakken et al. 2006; Barrett et al. 2006; Hatch et al. 2008), which is less than the $8-15 \%$ previously indicated (Boertmann et al. 1996; Bakken et al. 2006). This disparity must be ascribed to the higher quality of the current data, and does not document a shift in the size of the populations.

\section{Distribution}

By far the majority of the population is distributed along the West Greenland coast, with two key areas: Maniitsoq and Qaanaaq. The West Greenland population estimate of breeding kittiwakes falls within the range of former estimates, although the regional distribution is somewhat different from previous perceptions (Boertmann et al. 1996; Nyeland \& Mathæussen 2004), in that the Qaanaaq area is now identified as equally or more important than the Maniitsoq area (Table 2).

In contrast to West Greenland, the East Greenland coast is much more influenced by sea ice in spring and summer (Hansen et al. 2008; Hvidegaard et al. 2008), and the 2008 aerial survey confirmed that this coast holds only a sparse and scattered breeding population of kittiwakes. All the important colonies are located at the major coastal polynyas: the Scoresby Sund Polynya (five colonies, including the largest East Greenland colony, with 1300 AONs), the Wollaston Forland Polynya (three small colonies, with a maximum of 75 AONs) and the Northeast Water Polynya (one colony, with 873 AONs). The remaining three colonies $(<50 \mathrm{AONs})$ are in the northern Dove Bay, which becomes free of ice relatively early. New information (available after the 2008 survey) indicates that more colonies of minor sizes may be found along this remote and inaccessible coast of south-east Greenland: in 2006 about five small colonies with 20-120 AONs (in total ca. 340 AONs) were located between Tasilaq and Umiivik (A. Rosing-Asvid, pers. comm.). However, even if more colonies remain unknown along this remote and harsh coastline of East Greenland, they are likely to be small and unstable.

\section{Trends}

West Greenland. The size of the Qaanaaq population, in the north, is much larger than the former estimates of 14000 from 1987 (Kampp 1990). However, the original 1987 estimates were crude because these colonies were visited primarily for monitoring thick-billed murres (Uria lomvia). Moreover, nests at the two largest colonies are located high above sea level (up to ca. $400 \mathrm{~m}$ a.s.l.), and 
are often dispersed over large cliff areas, which may have caused an underestimation in 1987 (Merkel et al. 2007). Archived photos from 1987 of selected areas indicate that the kittiwakes were at least as plentiful then as today. In one colony (76014) fewer birds were counted in the 2006 photographs (2793 birds in 1987 versus 2484 birds in 2006; 17 colony sections), whereas the opposite was the case in another colony (77002; 659 birds in 1987 versus 733 birds in 2006; six colony sections). In total, the comparison of 23 colony sections indicates a small population decline of ca. 7\% (Greenland Institute of Natural Resources, unpubl. data). Nearby High-Arctic colonies of kittiwakes in Barrow Strait, Canada, are doing well, and the area has experienced significant increases in the breeding population since the 1970s (Mallory et al. 2009).

The breeding population of the north-west region, on the other hand, appears to have experienced a substantial decline, indicated by the large number of abandoned colonies (Fig. 1), as well as large reductions in colony sizes (Burnham et al. 2005; Boertmann 2006). The updated figures show a decrease of 39, 79 and 36\% in number of AONs in Upernavik, Uummannaq and the Disko Bay area (from Ilulissat to Aasiaat), respectively, compared with previous information (Boertmann et al. 1996). However, it is uncertain when these reductions have occurred because of the limited survey effort in the past (Burnham et al. 2005; Boertmann 2006). The Uummannaq area shows the most drastic declines (from 268000 AONs in 1920 to 1100 AONs in 2000), with large reductions in the number of colonies as well as birds, a decline that may have happened at any time during the past 90 years, given that many colonies had not been surveyed since 1920 (Burnham et al. 2005). However, data from a few larger colonies indicate some reduction by 1949 , and a survey in 1984 showed that several large colonies were abandoned by then (Burnham et al. 2005). In the Disko Bay region, and the fjords immediately to the south of the bay, substantial decreases were recorded in 2003. For example, by 2003 the populations in the fjords Arfersiorfik ( $n=15$ colonies and 3099 AONs in 1954) and Nordre Strømfjord $(n=9$ colonies with 715 AONs in 1954) were reduced by 75 and $88 \%$, respectively. Even larger reductions may have taken place in the Disko Bay, but presumed exaggerated survey results in the 1950s preclude sound comparisons (Boertmann 2006).

The latest survey (2003) of the Maniitsoq area concluded that the breeding population of this key breeding area had been halved since 1977 (Nyeland \& Mathæussen 2004), and for some of the larger colonies, this decrease had occurred by the early 1990s (Nyeland 2004). Similarly, the breeding population of the surveyed colonies in south Greenland has decreased by $60 \%$ since the previous (1970-80s) counts (Boertmann 2004). The south- west and south Greenland regions show a common characteristic. Even though the total number of AONs has decreased, the population is now more dispersed, as several new and small colonies have been established (Boertmann 2004; Nyeland \& Mathæussen 2004). Such small colonies are often unstable over time, but this phenomenon may give a false impression of a healthy and increasing population (Nyeland \& Mathæussen 2004).

East Greenland. In 2004 the population in north-east Greenland seemed to have increased considerably (Gilg 2005). This was, however, moderated in 2008, when six of these colonies had decreased from 700 to 302 AONs (see the Appendix). Despite this decrease, the conditions for kittiwakes have probably improved in recent years, because less drift ice has occurred along the coasts in the summer months (Johannessen et al. 2004; Hansen et al. 2008; Hvidegaard et al. 2008). This is underlined by the fact that the boreal lesser black-backed gull (Larus fuscus) has extended its breeding range to these coasts of Greenland in recent years (Boertmann 2008).

Reasons for decline. The exploitation of seabirds in Greenland (hunting and egg collecting) has been a key factor for the decrease in several breeding seabird populations, such as the thick-billed murre and common eider (Somateria mollisima) (Kampp et al. 1994; Merkel 2004), and may also be a contributing factor for the declines in the kittiwake population. Hunters in Greenland are annually obliged to report the number of birds taken each month, and these bag records date back to 1993. During the first year as many as 63000 birds were reported to have been killed, but this decreased gradually to about 32000 in 2001 (Government of Greenland, unpubl. hunting statistics 2008). From 2002 the open season was shortened from 16 August-31 May to 1 September-15 February (Government of Greenland 2002), after which the annual harvest declined further, and has stabilized at roughly 8000 birds (Government of Greenland, unpubl. hunting statistics 2008). These figures must be considered as index values because an uncertain number of birds are not reported, however, the pre-2002 records indicate that more than half of the annual catches were from the spring period. Ring recoveries indicate that there was a higher fraction of Greenlandic breeders in the spring catches than in the autumn catches, whereas the autumn catches had a higher fraction of younger birds and of adult breeders from abroad (Lyngs 2003). Thus, the spring harvest may have been more harmful to the Greenlandic breeding population than the autumn harvest, both in terms of direct mortality and from disturbances as a result of hunting close to breeding 
colonies. However, a population effect of the reduced hunting season has yet to be observed. So far, the linkage between the population decline and the harvest has not been as clear for kittiwakes as for other seabirds harvested in Greenland (Nyeland 2004).

Kittiwakes are pelagic surface feeders, which, particularly in the breeding season, makes them more vulnerable to reduced food availability (Furness $\&$ Tasker 2000). In some areas of the North Atlantic, the observed reductions in breeding populations as well as reduced reproductive success of kittiwakes has been connected to limited access to suitable food resources as a result of large-scale shifts in marine ecosystems (Ekker 2008). In Canada, a clear demarcation in population trends and biology between kittiwake colonies in the high Arctic and along the Atlantic coast give a similar picture as in Greenland, of healthy colonies in the High Arctic and colonies with reduced breeding populations further south (Gaston et al. 2009). The colonies in Atlantic Canada have decreased because of changes in feeding regimes (Regehr \& Montevecchi 1997; Gaston et al. 2009). Little is known about the diet of kittiwakes in Greenland; however, to our knowledge, severe breeding failure has not been reported from Greenlandic colonies.

Future surveys may show if the reduced hunting season will have an effect on the size of the breeding population. Other questions that are vital to address in Greenland include reproduction success, diet, impacts of climate change, etc., data which are also relevant for the management of the population. We therefore strongly recommend that a kittiwake monitoring programme is initiated in Greenland.

\section{Acknowledgements}

We thank the Danish Nature Protection Agency for financial support for the kittiwake surveys in 2005 and 2006 (journal no. 127/001-0192). We are grateful to Birger Knudsen for providing up-to-date kittiwake information from the Paamiut area, and to Kasper Johansen and Morten Bjerrum (National Environmental Research Institute) for GIS support. For safe navigation during the recent ship-based kittiwake surveys, we thank Finn Steffens (2005), Naimmanngitsoq Petersen (2006) and Jens Kjeldsen (2007), and Leif Petersen, Danish Air Survey, was an excellent pilot during the aerial surveys in East Greenland in 2008. Thanks also to Aevar Petersen for Icelandic literature, and to Morten Frederiksen, as well as two reviewers, for improving this manuscript.

\section{References}

Anker-Nilssen T., Bakken V., Strøm H., Golovkin A.N., Bianki V.V. \& Tatarinkova I.P. 2000. The status of marine birds breeding in the Barents Sea region. Norsk Polarinstitutt Rapportserie 113. Tromsø: Norwegian Polar Institute.

Baird P.H. 1990. Influence of abiotic factors and prey distribution on diet and reproductive success in three seabird species in Alaska. Ornis Scandinavica 21, 224-235.

Bakken V., Boertmann D., Mosbech A., Olsen B., Petersen A., Strøm H. \& Goodwin H. 2006. Nordic seabird colony databases. Results of a Nordic project on seabird breeding colonies in Faroes, Greenland, Iceland, Jan Mayen and Svalbard. TemaNord 2006: 512. Copenhagen: Nordic Council of Ministers.

Barrett R.T., Lorentsen S.-H. \& Anker-Nilssen T. 2006. The status of breeding seabirds in mainland Norway. Atlantic Seabirds 8, 97-126.

Boertmann D. 2004. Seabird colonies and moulting harlequin ducks in south Greenland. Results of a survey in July 2003. Research Notes from NERI 191. Roskilde, Denmark: National Environmental Research Institute.

Boertmann D. 2006. Optolling af ridekolonier i Disko Bugt, Arfersiorfik Fjord og Nordre Strømfjord i 2005. (Survey of kittiwake colonies in Disko Bay, Arfersiorfik Fjord and Nordre Strømfjord in 2005.) Arbejdsrapport fra DMU 225. Roskilde, Denmark: National Environmental Research Institute.

Boertmann D. 2007. Grønlands Rødliste 2007. (The Greenland Red List 2007.) Roskilde, Denmark: National Environmental Research Institute.

Boertmann D. 2008. The lesser black-backed gull, Larus fuscus, in Greenland. Arctic 61, 129-133.

Boertmann D., Mosbech A., Falk K. \& Kampp K. 1996. Seabird colonies in western Greenland $\left(60^{\circ}-79^{\circ} 30^{\prime}\right.$ N. lat.). Technical Report 170. Roskilde, Denmark: National Environmental Research Institute.

Boertmann D., Olsen K. \& Nielsen R.D. 2009. Seabirds and marine mammals in northeast Greenland. Technical Report 721. Roskilde, Denmark: National Environmental Research Institute, Aarhus University.

Bornaechea P.G. \& Gardarsson A. 2006. Fuglabjörg á Snæfellsnesi árid 2005. (Seabird colonies in Snæfellsnesi in 2005.) Bliki 27, 51-54.

Boulinier T., Danchin E., Monnat J.Y., Doutrelant C. \& Cadiou B. 1996. Timing of prospecting and the value of information in a colonial breeding bird. Journal of Avian Biology 27, 252-256.

Burnham W., Burnham K.K. \& Cade T.J. 2005. Past and present assessments of bird life in Uummannaq District, West Greenland. Dansk Ornitologisk Forenings Tidsskrift 99, 196-208.

Cadiou B. \& Monnat J.Y. 1996. Parental attendance and squatting in the kittiwake Rissa tridactyla during the rearing period. Bird Study 43, 164-171.

Carscadden J.E., Montevecchi W.A., Davoren G.K. \& Nakashima B.S. 2002. Trophic relationships among capelin (Mallotus villosus) and seabirds in a changing ecosystem. ICES Journal of Marine Science 59, 1027-1033.

Cramp S. \& Simmons K.E.L. (eds.) 1983. The birds of the western Palearctic. Vol. 3. Oxford: Oxford University Press.

Ekker M. (ed.) 2008. Vest-Nordiske sjøfugler i et presset havmiljø. (West Nordic seabirds in a marine environment under pressure.) 
TemaNord 2008:573. Copenhagen: Nordic Council of Ministers.

Frederiksen M., Wanless S., Harris M.P., Rothery P. \& Wilson L.J. 2004. The role of industrial fisheries and oceanographic change in the decline of North Sea black-legged kittiwakes. Journal of Applied Ecology 41, 1129-1139.

Furness R.W. \& Tasker M.L. 2000. Seabird-fishery interactions: quantifying the sensitivity of seabirds to reductions in sandeel abundance, and identification of key areas for sensitive seabirds in the North Sea. Marine Ecology Progress Series 202, 253-264.

Gardarsson A. 2006. Nýlegar breytingar á fjölda íslenskra bjargfugla. (Recent changes in numbers of Icelandic colonial seabirds.) Bliki 27, 13-27.

Gaston A.J., Bertram D.F., Boyne A.W., Chardine J.W., Davoren G., Diamond A.W., Hedd A., Montevecchi W.A., Hipfner J.M., Lemon M.J.F., Mallory M.L., Rail J.-F. \& Robertson G.J. 2009. Changes in Canadian seabird populations and ecology since 1970 in relation to changes in oceanography and food webs. Environmental Reviews 17, 267-286.

Gilg O. (ed.). 2005. Ecopolaris-Tara 5 expedition to NE Greenland 2004. Francheville, France: Groupe de Recherches en Ecologie Arctique.

Government of Greenland 2002. Hjemmestyrets bekendtgørelse nr. 38 af 6. december 2001 om beskyttelse af fugle. (Executive Order no. 38 of 6 December 2001 on the protection of birds.) Nuuk: Government of Greenland.

Hansen B.U., Sigsgaard C., Rasmussen L., Cappelen J., Hinkler J., Mernild S.H., Petersen D., Tamstorf M.P., Rasch M. \& Hasholt B. 2008. Present-day climate at Zackenberg. In H. Meltofte et al. (eds.): High-Arctic ecosystem dynamics in a changing climate. Pp. 111-149. Amsterdam: Elsevier.

Hatch S.A., Byrd G.V., Irons D.B. \& Hunt G.L. 1993. Status and ecology of kittiwakes (Rissa tridactyla and $R$. brevirostris) in the North Pacific. In K. Vermeer et al. (eds.). The status, ecology and conservation of marine birds in the North Pacific. Pp. 140-153. Ottawa: Canadian Wildlife Service Special Publication.

Hatch S.A. \& Hatch M.A. 1988. Colony attendance and population monitoring of black-legged kittiwakes on the Semidi Islands, Alaska. Condor 90, 613-620.

Hatch S.A., Robertson G.J. \& Baird H.P. 2008. Black-legged kittiwake (Rissa tridactyla). In A. Poole (ed.): The birds of North America online. Ithaca, NY: Cornell Laboratory of Ornithology.

Hvidegaard S.M., Forsberg R., Hanson S., Skourup H. \& Pedersen L.T. 2008. Sea ice conditions off NW and NE Greenland from satellite measurements, airborne and in-situ data: contract report for Greenland Bureau of Minerals and Petroleum. Copenhagen: National Space Institute and Center for Oceans and Ice, Danish Meteorological Institute.

Johannessen O.M., Bengtsson L., Miles M.W., Kuzmina S.I., Semenov V.A., Alekseev G.V., Nagurnyi A.P., Zakharov V.F., Bobylev L.P., Pettersson L.H., Hasselmann K. \& Cattle H.P. 2004. Arctic climate change: observed and modeled temperature and sea-ice variability. Tellus Series A 56, 328-341.

Kampp K. 1990. The thick-billed murre population of the Thule District, Greenland. Arctic 43, 115-120.

Kampp K., Nettleship D.N. \& Evans G.H. 1994. Thick-billed murres of Greenland: status and prospects. In D.N. Nettleship et al. (eds.): Seabirds on islands, threats, case-studies and action plans. Pp. 133-154. Cambridge: BirdLife International.

Lyngs P. 2003. Black-legged kittiwake Rissa tridactyla recoveries. Dansk Ornitologisk Forenings Tidskrift 97, 92-100.

Mallory M.L., Akearok J.A. \& Gaston A.J. 2009. Status of High Arctic black-legged kittiwake (Rissa tridactyla) colonies in Barrow Strait, Nunavut, Canada. Arctic 62, 96-101.

Mavor R.A., Heubeck M., Schmitt S. \& Parsons M. 2006. Seabird numbers and breeding success in Britain and Ireland, 2006. UK Conservation Report 31. Petersborough: Joint Nature Conservation Committee.

Merkel F.R. 2004. Evidence of population decline in common eiders breeding in western Greenland. Arctic 57, 27-36.

Merkel F. \& Barry T. (eds.) 2008. Seabird harvest in the Arctic. CAFF Technical Report 16. Akureyri: Conservation of Arctic Flora and Fauna International Secretariat.

Merkel F.R., Labansen A.L. \& Witting L. 2007. Monitering af lomvier og rider i Qaanaaq Kommune, 2006. (Monitoring of thick-billed murre and kittiwakes in the municipality of Qaanaaq, 2006.) Teknisk Rapport 69. Pinngortitaleriffik: Greenland Institute of Natural Resources.

Merkel F.R., Rasmussen L.M. \& Rosing-Asvid A. 2010. Seabirds and marine mammals in south and southeast Greenland, June 2008. Technical Report 81. Pinngortitaleriffik: Greenland Institute of Natural Resources.

Mitchell P.I., Newton S.F., Ratcliffe N. \& Dunn T.E. 2004. Seabird populations of Britain and Ireland. London: T. \& A.D. Poyser.

Nyeland J. 2004. Apparent trends in the black-legged kittiwake in Greenland. Waterbirds 27, 342-349.

Nyeland J. 2007. Monitering af lomviekolonierne Kippaku og Apparsuit $i$ det nordlige Upernavik, 2002. (Monitoring the thick-billed murre colonies Kippaku and Apparsuit in northern Upernavik.) Teknisk Rapport 65. Pinngortitaleriffik: Greenland Institute of Natural Resources.

Nyeland J. \& Mathæussen H. 2004. Monitering af havfuglekolonier i Maniitsoq Kommune 2003. (Monitoring seabird colonies in the municipality of Maniitsoq 2003.) Teknisk Rapport 59. Pinngortitaleriffik: Greenland Institute of Natural Resources.

Regehr H.M. \& Montevecchi W.A. 1997. Interactive effects of food shortage and predation on breeding failure of black-legged kittiwakes: indirect effects of fisheries activities and implications for indicator species. Marine Ecology Progress Series 155, 249-260.

Sunnanå K. \& Fossheim M. 2008. Forvaltningsplan Barentshavet-rapport fra overvåkingsgruppen 2008. (Management plan Barents Sea-report from the monitoring group.) Fisken og Havet Special Issue 1B. Bergen: Institute of Marine Research. 


\section{Appendix}

Latest count of all registrated breeding colonies of black-legged kittiwakes in Greenland. Based on data from the seabird breeding colony database maintained by the National Environmental Research Institute. In West Greenland, the area name is listed by municipality. In East Greenland the area name is listed by name of site.

\begin{tabular}{|c|c|c|c|c|c|}
\hline Area & Colony number & Date & Qualitya $^{a}$ & Unitb & Min pairs ${ }^{c}$ \\
\hline \multicolumn{6}{|l|}{ North } \\
\hline Qaanaaq & 77002 & 25 July 2006 & $\mathrm{H}$ & $P$ & 12860 \\
\hline Qaanaaq & 76014 & 27 July 2006 & $\mathrm{H}$ & $P$ & 18707 \\
\hline Qaanaaq & 76013 & 28 July 2006 & $\mathrm{H}$ & $P$ & 2457 \\
\hline Qaanaaq & 76012 & 29 July 2006 & $\mathrm{H}$ & $P$ & 1642 \\
\hline \multicolumn{6}{|l|}{ North-west } \\
\hline Upernavik & 73069 & 16 July 1998 & $\mathrm{~L}$ & 1 & 10 \\
\hline Upernavik & 73056 & 8 July 2007 & $\mathrm{H}$ & $\mathrm{N}$ & 43 \\
\hline Upernavik & 73043 & 8 July 2007 & $\mathrm{H}$ & $\mathrm{N}$ & 152 \\
\hline Upernavik & 73026 & 6 July 2007 & $\mathrm{H}$ & $\mathrm{N}$ & 13 \\
\hline Upernavik & 73025 & 6 July 2007 & $\mathrm{H}$ & $\mathrm{N}$ & 13 \\
\hline Upernavik & 73011 & 6 July 2007 & $\mathrm{H}$ & $\mathrm{N}$ & 608 \\
\hline Upernavik & 73010 & 31 July 2002 & $\mathrm{H}$ & I & 437 \\
\hline Upernavik & 73009 & 1 August 2002 & $\mathrm{H}$ & 1 & 2186 \\
\hline Upernavik & 73008 & 6 July 2007 & $\mathrm{H}$ & $\mathrm{N}$ & 219 \\
\hline Upernavik & 73007 & 5 July 2007 & $\mathrm{H}$ & $\mathrm{N}$ & 0 \\
\hline Upernavik & 72151 & 13 July 1999 & $\mathrm{H}$ & $\mathrm{N}$ & 2 \\
\hline Upernavik & 72140 & 13 July 1999 & $\mathrm{H}$ & $\mathrm{N}$ & 2 \\
\hline Upernavik & 72137 & 15 July 1998 & $\mathrm{H}$ & $\mathrm{N}$ & 16 \\
\hline Upernavik & 72096 & 7 July 1998 & $\mathrm{H}$ & $\mathrm{N}$ & 26 \\
\hline Upernavik & 72092 & 13 July 1998 & $\mathrm{~L}$ & 1 & 20 \\
\hline Upernavik & 72083 & 16 July 1998 & $\mathrm{~L}$ & I & 65 \\
\hline Upernavik & 72078 & 15 July 1998 & $\mathrm{H}$ & $\mathrm{N}$ & 57 \\
\hline Upernavik & 72047 & 12 July 1998 & $M$ & $P$ & 0 \\
\hline Upernavik & 72038 & 13 July 1998 & $\mathrm{~L}$ & 1 & 65 \\
\hline Upernavik & 72037 & 11 July 2007 & $\mathrm{H}$ & $\mathrm{N}$ & 0 \\
\hline Upernavik & 72036 & 4 July 1998 & $\mathrm{H}$ & $\mathrm{N}$ & 8 \\
\hline Upernavik & 72035 & 1 July 2007 & $\mathrm{H}$ & $\mathrm{N}$ & 130 \\
\hline Upernavik & 72034 & 1 July 2007 & $\mathrm{H}$ & $\mathrm{N}$ & 12 \\
\hline Upernavik & 72033 & 14 July 1998 & $\mathrm{~L}$ & 1 & 7 \\
\hline Upernavik & 72032 & 13 July 1998 & $\mathrm{H}$ & $\mathrm{N}$ & 9 \\
\hline Upernavik & 72031 & 13 July 1998 & $L$ & 1 & 39 \\
\hline Upernavik & 72027 & 1 July 2007 & $\mathrm{H}$ & $\mathrm{N}$ & 48 \\
\hline Upernavik & 72026 & 18 July 1994 & $M$ & $P$ & 0 \\
\hline Upernavik & 72025 & 11 July 2007 & $M$ & $\mathrm{~N}$ & 104 \\
\hline Upernavik & 72024 & 13 July 1998 & $M$ & $P$ & 0 \\
\hline Upernavik & 72023 & 4 July 1998 & $M$ & $P$ & 0 \\
\hline Upernavik & 72022 & 14 July 2000 & $M$ & $P$ & 0 \\
\hline Upernavik & 72020 & 13 July 1998 & $\mathrm{H}$ & $\mathrm{N}$ & 0 \\
\hline Upernavik & 72018 & 13 July 1998 & $\mathrm{H}$ & $\mathrm{N}$ & 192 \\
\hline Upernavik & 72017 & 1 July 2007 & $\mathrm{H}$ & $\mathrm{N}$ & 3 \\
\hline Upernavik & 72016 & 8 July 1998 & $M$ & $P$ & 0 \\
\hline Upernavik & 72014 & 9 July 2007 & $\mathrm{H}$ & $\mathrm{N}$ & 994 \\
\hline Upernavik & 72013 & 26 July 1999 & $\mathrm{H}$ & $\mathrm{N}$ & 83 \\
\hline Upernavik & 72011 & 26 July 1999 & $\mathrm{H}$ & $\mathrm{N}$ & 145 \\
\hline Upernavik & 72009 & 28 June 2007 & $\mathrm{H}$ & 1 & 465 \\
\hline Upernavik & 72008 & 8 July 2008 & $\mathrm{H}$ & $\mathrm{N}$ & 0 \\
\hline Upernavik & 72005 & 9 July 1999 & $\mathrm{H}$ & $\mathrm{N}$ & 57 \\
\hline Uummannaq & 72002 & 10 July 2000 & $\mathrm{H}$ & 1 & 228 \\
\hline Uummannaq & 71090 & 18 July 2000 & $\mathrm{H}$ & $\mathrm{N}$ & 6 \\
\hline Uummannaq & 71087 & 18 July 2000 & $\mathrm{H}$ & $\mathrm{N}$ & 80 \\
\hline Uummannaq & 71086 & 18 July 2000 & $\mathrm{H}$ & $\mathrm{N}$ & 4 \\
\hline
\end{tabular}


Appendix Continued

\begin{tabular}{|c|c|c|c|c|c|}
\hline Area & Colony number & Date & Quality $^{\mathrm{a}}$ & Unit $^{\mathrm{b}}$ & Min pairs ${ }^{c}$ \\
\hline Uummannaq & 71084 & 18 July 2000 & $\mathrm{H}$ & $\mathrm{N}$ & 21 \\
\hline Uummannaq & 71050 & 18 July 2000 & $\mathrm{H}$ & $\mathrm{N}$ & 60 \\
\hline Uummannaq & 71026 & 16 July 2000 & $\mathrm{H}$ & $P$ & 0 \\
\hline Uummannaq & 71025 & 16 July 2000 & $\mathrm{H}$ & N & 125 \\
\hline Uummannaq & 71023 & 18 July 2000 & $\mathrm{H}$ & $\mathrm{N}$ & 4 \\
\hline Uummannaq & 71015 & 2 July 2000 & M & $\mathrm{N}$ & 180 \\
\hline Uummannaq & 71011 & 13 July 2000 & $\mathrm{H}$ & $P$ & 0 \\
\hline Uummannaq & 71010 & 13 July 2000 & $\mathrm{H}$ & $P$ & 0 \\
\hline Uummannaq & 71009 & 13 July 2000 & $\mathrm{H}$ & N & 2 \\
\hline Uummannaq & 71008 & 13 July 2000 & $\mathrm{H}$ & $P$ & 0 \\
\hline Uummannaq & 71007 & 13 July 2000 & $\mathrm{H}$ & P & 0 \\
\hline Uummannaq & 70114 & 13 July 2000 & $\mathrm{H}$ & $P$ & 0 \\
\hline Uummannaq & 70113 & 13 July 2000 & $\mathrm{H}$ & $P$ & 0 \\
\hline Uummannaq & 70112 & 13 July 2000 & $\mathrm{H}$ & $\mathrm{N}$ & 2 \\
\hline Uummannaq & 70111 & 12 July 2000 & $\mathrm{H}$ & $P$ & 0 \\
\hline Uummannaq & 70109 & 12 July 2000 & $\mathrm{H}$ & P & 0 \\
\hline Uummannaq & 70106 & 15 July 2000 & $\mathrm{H}$ & $\mathrm{P}$ & 0 \\
\hline Uummannaq & 70101 & 13 July 2000 & $\mathrm{H}$ & $P$ & 0 \\
\hline Uummannaq & 70099 & 13 July 2000 & $\mathrm{H}$ & $P$ & 0 \\
\hline Uummannaq & 70098 & 13 July 2000 & $\mathrm{H}$ & $P$ & 0 \\
\hline Uummannaq & 70097 & 12 July 2000 & M & $\mathrm{P}$ & 0 \\
\hline Uummannaq & 70095 & 12 July 2000 & $\mathrm{H}$ & $P$ & 0 \\
\hline Uummannaq & 70090 & 12 July 2000 & $\mathrm{H}$ & $P$ & 0 \\
\hline Uummannaq & 70088 & 12 July 2000 & $\mathrm{H}$ & $P$ & 0 \\
\hline Uummannaq & 70086 & 8 July 2000 & $\mathrm{H}$ & $P$ & 0 \\
\hline Uummannaq & 70079 & 8 July 2000 & $\mathrm{H}$ & $P$ & 0 \\
\hline Uummannaq & 70072 & 8 July 2000 & $\mathrm{H}$ & $P$ & 0 \\
\hline Uummannaq & 70069 & 8 July 2000 & $\mathrm{H}$ & $\mathrm{P}$ & 0 \\
\hline Uummannaq & 70068 & 8 July 2000 & $\mathrm{H}$ & $\mathrm{P}$ & 0 \\
\hline Uummannaq & 70065 & 8 July 2000 & $\mathrm{H}$ & $P$ & 0 \\
\hline Uummannaq & 70064 & 12 July 2000 & $\mathrm{H}$ & $P$ & 0 \\
\hline Uummannaq & 70053 & 15 July 2000 & $\mathrm{H}$ & $P$ & 0 \\
\hline Uummannaq & 70049 & 15 July 2000 & $\mathrm{H}$ & $\mathrm{P}$ & 0 \\
\hline Uummannaq & 70042 & 7 July 2000 & $\mathrm{H}$ & $P$ & 0 \\
\hline Uummannaq & 70026 & 4 July 2000 & $\mathrm{H}$ & N & 20 \\
\hline Qeqertarsuaq & 70005 & 3 September 1995 & L & 1 & 65 \\
\hline Qeqertarsuaq & 69116 & 15 July 2001 & $\mathrm{H}$ & & 0 \\
\hline Qeqertarsuaq & 69064 & 22 July 2001 & $L$ & $\mathrm{~N}$ & 10 \\
\hline Qeqertarsuaq & 69063 & 15 July 2001 & $\mathrm{H}$ & & 0 \\
\hline Qeqertarsuaq & 69001 & 11 July 2005 & M & $P$ & 0 \\
\hline Qeqertarsuaq & 68012 & 11 July 2005 & $\mathrm{~L}$ & $P$ & 0 \\
\hline Ilulissat & 69129 & 7 July 2005 & $\mathrm{H}$ & $P$ & 15 \\
\hline Ilulissat & 69118 & 6 July 2005 & $\mathrm{H}$ & $P$ & 0 \\
\hline Ilulissat & 69103 & 5 July 2004 & M & $P$ & 0 \\
\hline Ilulissat & 69081 & 6 June 2007 & $\mathrm{H}$ & N & 0 \\
\hline Ilulissat & 69077 & 5 July 2005 & $\mathrm{H}$ & $\mathrm{N}$ & 1 \\
\hline Ilulissat & 69049 & 5 July 2005 & M & $P$ & 2783 \\
\hline Ilulissat & 69048 & 6 July 2005 & $\mathrm{H}$ & N & 90 \\
\hline Ilulissat & 69046 & 6 July 2005 & $\mathrm{H}$ & & 0 \\
\hline Ilulissat & 69045 & 6 July 2005 & $\mathrm{H}$ & N & 42 \\
\hline Ilulissat & 69043 & 6 July 2005 & $\mathrm{H}$ & N & 44 \\
\hline Ilulissat & 69042 & 6 July 2005 & $\mathrm{H}$ & & 0 \\
\hline Ilulissat & 69041 & 6 July 2005 & $\mathrm{H}$ & N & 210 \\
\hline Ilulissat & 69040 & 7 July 2005 & $\mathrm{H}$ & $\mathrm{N}$ & 18 \\
\hline Ilulissat & 69039 & 7 July 2005 & $\mathrm{H}$ & N & 136 \\
\hline Ilulissat & 69038 & 6 July 2005 & $\mathrm{H}$ & $P$ & 7072 \\
\hline
\end{tabular}


Appendix Continued

\begin{tabular}{|c|c|c|c|c|c|}
\hline Area & Colony number & Date & Quality $^{a}$ & Unit $^{b}$ & Min pairs ${ }^{c}$ \\
\hline |lulissat & 69037 & 6 July 2005 & M & $\mathrm{N}$ & 1077 \\
\hline Ilulissat & 69036 & 6 July 2005 & $\mathrm{H}$ & & 0 \\
\hline Ilulissat & 69035 & 6 July 2005 & M & $\mathrm{P}$ & 800 \\
\hline Ilulissat & 69034 & 6 July 2005 & $\mathrm{H}$ & $\mathrm{P}$ & 0 \\
\hline Ilulissat & 69033 & 6 July 2005 & $\mathrm{H}$ & $\mathrm{P}$ & 9514 \\
\hline Ilulissat & 69032 & 7 July 2005 & $\mathrm{H}$ & N & 45 \\
\hline Ilulissat & 69030 & 7 July 2005 & $\mathrm{H}$ & $\mathrm{N}$ & 27 \\
\hline Ilulissat & 69028 & 7 July 2005 & $\mathrm{H}$ & & 0 \\
\hline Ilulissat & 69027 & 7 July 2005 & $\mathrm{H}$ & $\mathrm{N}$ & 111 \\
\hline Ilulissat & 69026 & 7 July 2005 & $\mathrm{H}$ & $\mathrm{P}$ & 0 \\
\hline Ilulissat & 69025 & 7 July 2005 & $\mathrm{H}$ & & 0 \\
\hline Ilulissat & 69022 & 8 July 2005 & $\mathrm{H}$ & I & 0 \\
\hline Ilulissat & 69020 & 5 July 2005 & $\mathrm{H}$ & & 0 \\
\hline Ilulissat & 69019 & 5 July 2005 & $\mathrm{H}$ & & 0 \\
\hline Ilulissat & 69018 & 5 July 2005 & $\mathrm{H}$ & & 0 \\
\hline Ilulissat & 69017 & 4 July 2005 & $\mathrm{H}$ & & 0 \\
\hline Ilulissat & 69016 & 4 July 2005 & $\mathrm{H}$ & & 0 \\
\hline Ilulissat & 69015 & 4 July 2005 & $\mathrm{H}$ & $\mathrm{N}$ & 49 \\
\hline Ilulissat & 69014 & 4 July 2005 & $\mathrm{H}$ & & 0 \\
\hline Ilulissat & 69011 & 5 July 1976 & & 1 & 0 \\
\hline Ilulissat & 69010 & 5 July 1976 & & $P$ & 0 \\
\hline Ilulissat & 69007 & 6 July 1976 & M & $\mathrm{P}$ & 0 \\
\hline Ilulissat & 69003 & 5 July 1976 & & 1 & 0 \\
\hline Ilulissat & 68036 & 6 July 1976 & & $P$ & 0 \\
\hline Ilulissat & 68035 & 6 July 1976 & M & $P$ & 0 \\
\hline Qasigiannguit & 68209 & 8 July 2005 & $\mathrm{H}$ & 1 & 1 \\
\hline Qasigiannguit & 68203 & 9 July 2005 & $\mathrm{H}$ & $\mathrm{N}$ & 314 \\
\hline Qasigiannguit & 68138 & 9 July 2005 & $\mathrm{H}$ & $\mathrm{N}$ & 1 \\
\hline Qasigiannguit & 68112 & 9 July 2005 & $\mathrm{H}$ & $\mathrm{N}$ & 2 \\
\hline Qasigiannguit & 68106 & 26 June 1976 & & 1 & 0 \\
\hline Qasigiannguit & 68081 & 23 July 1997 & M & $P$ & 0 \\
\hline Qasigiannguit & 68054 & 21 July 2005 & $\mathrm{H}$ & $P$ & 0 \\
\hline Qasigiannguit & 68026 & 8 July 2005 & $\mathrm{H}$ & & 0 \\
\hline Qasigiannguit & 68025 & 8 July 2005 & $\mathrm{H}$ & & 0 \\
\hline Qasigiannguit & 68020 & 8 July 2005 & $\mathrm{H}$ & $P$ & 5 \\
\hline Qasigiannguit & 68017 & 8 July 2005 & $\mathrm{H}$ & $P$ & 0 \\
\hline Qasigiannguit & 68014 & 8 July 2005 & $\mathrm{H}$ & & 0 \\
\hline Aasiaat & 68029 & July 2006 & M & $\mathrm{P}$ & 0 \\
\hline Kangaatsiaq & 68219 & 12 July 2005 & $\mathrm{H}$ & $\mathrm{N}$ & 3 \\
\hline Kangaatsiaq & 68202 & 19 July 2005 & $\mathrm{H}$ & $\mathrm{N}$ & 9 \\
\hline Kangaatsiaq & 68159 & 14 July 2005 & $\mathrm{H}$ & $\mathrm{P}$ & 85 \\
\hline Kangaatsiaq & 68158 & 14 July 2005 & $\mathrm{H}$ & $\mathrm{N}$ & 195 \\
\hline Kangaatsiaq & 68129 & 20 July 2005 & $\mathrm{H}$ & $P$ & 0 \\
\hline Kangaatsiaq & 68123 & 14 July 2005 & $\mathrm{H}$ & $\mathrm{N}$ & 84 \\
\hline Kangaatsiaq & 68121 & 19 July 2005 & $\mathrm{H}$ & $\mathrm{N}$ & 12 \\
\hline Kangaatsiaq & 68095 & 14 July 2005 & $\mathrm{H}$ & $P$ & 0 \\
\hline Kangaatsiaq & 68094 & 14 July 2005 & $\mathrm{H}$ & $P$ & 0 \\
\hline Kangaatsiaq & 68093 & 14 July 2005 & $\mathrm{H}$ & $\mathrm{P}$ & 0 \\
\hline Kangaatsiaq & 68086 & 13 July 2005 & $\mathrm{H}$ & $\mathrm{P}$ & 0 \\
\hline Kangaatsiaq & 68085 & 13 July 2005 & $\mathrm{H}$ & $\mathrm{N}$ & 59 \\
\hline Kangaatsiaq & 68084 & 13 July 2005 & $\mathrm{H}$ & $\mathrm{N}$ & 243 \\
\hline Kangaatsiaq & 68083 & 13 July 2005 & $\mathrm{H}$ & $\mathrm{N}$ & 14 \\
\hline Kangaatsiaq & 68082 & 24 July 1997 & M & $P$ & 0 \\
\hline Kangaatsiaq & 68079 & 21 July 1997 & M & $P$ & 0 \\
\hline Kangaatsiaq & 68077 & 13 July 2005 & $\mathrm{H}$ & $\mathrm{N}$ & 90 \\
\hline Kangaatsiaq & 68072 & 11 July 1954 & M & UP & 41 \\
\hline
\end{tabular}


Appendix Continued

\begin{tabular}{|c|c|c|c|c|c|}
\hline Area & Colony number & Date & Quality $^{a}$ & Unit $^{b}$ & Min pairs ${ }^{c}$ \\
\hline Kangaatsiaq & 68067 & 20 July 2005 & $\mathrm{H}$ & $\mathrm{N}$ & 147 \\
\hline Kangaatsiaq & 68066 & 20 July 2005 & $\mathrm{H}$ & & 0 \\
\hline Kangaatsiaq & 68065 & 20 July 2005 & $\mathrm{H}$ & P & 0 \\
\hline Kangaatsiaq & 68061 & 21 July 2005 & $\mathrm{H}$ & $P$ & 0 \\
\hline Kangaatsiaq & 68059 & 21 July 2005 & $\mathrm{H}$ & $\mathrm{P}$ & 0 \\
\hline Kangaatsiaq & 68058 & 21 July 2005 & $\mathrm{H}$ & $\mathrm{P}$ & 0 \\
\hline Kangaatsiaq & 68055 & 21 July 2005 & $\mathrm{H}$ & $\mathrm{P}$ & 0 \\
\hline Kangaatsiaq & 67062 & 19 July 2005 & $\mathrm{H}$ & & 0 \\
\hline Kangaatsiaq & 67061 & 12 July 2005 & $\mathrm{H}$ & $P$ & 1 \\
\hline Kangaatsiaq & 67060 & 12 July 2005 & $\mathrm{H}$ & & 0 \\
\hline Kangaatsiaq & 67059 & 12 July 2005 & $\mathrm{H}$ & & 0 \\
\hline Kangaatsiaq & 67030 & 16 July 2006 & $\mathrm{H}$ & $\mathrm{N}$ & 38 \\
\hline Kangaatsiaq & 67027 & 16 July 2006 & $\mathrm{H}$ & N & 5 \\
\hline Kangaatsiaq & 67026 & 16 July 2006 & $\mathrm{H}$ & & 0 \\
\hline Kangaatsiaq & 67025 & 16 July 2006 & $\mathrm{H}$ & N & 37 \\
\hline Kangaatsiaq & 67024 & 16 July 2006 & M & $P$ & 0 \\
\hline Kangaatsiaq & 67011 & 16 July 2005 & $\mathrm{H}$ & N & 2 \\
\hline \multicolumn{6}{|l|}{ South-west } \\
\hline Sisimiut & 67017 & 16 July 2005 & $\mathrm{H}$ & & 0 \\
\hline Sisimiut & 67015 & 16 July 2005 & $\mathrm{H}$ & & 0 \\
\hline Sisimiut & 67014 & 16 July 2005 & $\mathrm{H}$ & & 0 \\
\hline Sisimiut & 66201 & 28 August 1993 & $L$ & $\mathrm{P}$ & 50 \\
\hline Sisimiut & 66028 & 20 July 1975 & M & & 0 \\
\hline Maniitsoq & 66044 & 22 July 2003 & & N & 118 \\
\hline Maniitsoq & 66043 & 22 July 2003 & & N & 23 \\
\hline Maniitsoq & 66021 & 28 June 1992 & M & $P$ & 0 \\
\hline Maniitsoq & 66008 & 22 July 2003 & & N & 10 \\
\hline Maniitsoq & 66007 & 22 July 2003 & & N & 67 \\
\hline Maniitsoq & 66005 & 22 July 2003 & & N & 39 \\
\hline Maniitsoq & 66003 & 22 July 2003 & M & $P$ & 0 \\
\hline Maniitsoq & 66002 & 22 July 2003 & & N & 14 \\
\hline Maniitsoq & 66001 & 21 July 2003 & & $\mathrm{~N}$ & 502 \\
\hline Maniitsoq & 65064 & 26 July 2003 & $\mathrm{H}$ & N & 1205 \\
\hline Maniitsoq & 65043 & 1980 & M & $P$ & 50 \\
\hline Maniitsoq & 65036 & 22 July 2003 & & $\mathrm{~N}$ & 103 \\
\hline Maniitsoq & 65030 & 22 July 2003 & & N & 43 \\
\hline Maniitsoq & 65029 & 22 July 2003 & & N & 41 \\
\hline Maniitsoq & 65028 & 22 July 2003 & & N & 164 \\
\hline Maniitsoq & 65027 & 22 July 2003 & M & $P$ & 0 \\
\hline Maniitsoq & 65026 & 22 July 2003 & & N & 12 \\
\hline Maniitsoq & 65024 & 22 July 2003 & M & $P$ & 0 \\
\hline Maniitsoq & 65023 & 22 July 2003 & & $\mathrm{~N}$ & 48 \\
\hline Maniitsoq & 65022 & 22 July 2003 & & N & 20 \\
\hline Maniitsoq & 65021 & 22 July 2003 & & N & 27 \\
\hline Maniitsoq & 65019 & 21 July 2003 & $\mathrm{H}$ & $\mathrm{N}$ & 11337 \\
\hline Maniitsoq & 65018 & 21 July 2003 & & N & 34 \\
\hline Maniitsoq & 65015 & 25 July 2003 & $\mathrm{H}$ & N & 3930 \\
\hline Maniitsoq & 65013 & 25 July 2003 & $\mathrm{H}$ & N & 1730 \\
\hline Maniitsoq & 65012 & 25 July 2003 & M & $P$ & 0 \\
\hline Maniitsoq & 65011 & 25 July 2003 & $\mathrm{H}$ & N & 1390 \\
\hline Maniitsoq & 65010 & 25 July 2003 & M & $P$ & 0 \\
\hline Maniitsoq & 65009 & 25 July 2003 & $\mathrm{H}$ & N & 3393 \\
\hline Maniitsoq & 65008 & 25 July 2003 & $\mathrm{H}$ & N & 715 \\
\hline Maniitsoq & 65004 & 26 July 2003 & $\mathrm{H}$ & N & 2400 \\
\hline Maniitsoq & 65003 & 26 July 2003 & $\mathrm{H}$ & N & 4770 \\
\hline Maniitsoq & 65002 & 26 July 2003 & $\mathrm{H}$ & $\mathrm{N}$ & 130 \\
\hline
\end{tabular}


Appendix Continued

\begin{tabular}{|c|c|c|c|c|c|}
\hline Area & Colony number & Date & Quality $^{a}$ & Unit $^{b}$ & Min pairs ${ }^{c}$ \\
\hline Maniitsoq & 65001 & 26 July 2003 & $\mathrm{H}$ & $\mathrm{N}$ & 100 \\
\hline Maniitsoq & 64200 & 4 July 1992 & $\mathrm{H}$ & $P$ & 6 \\
\hline Nuuk & 64035 & 28 June 2007 & $\mathrm{H}$ & $P$ & 48 \\
\hline Nuuk & 64023 & 6 July 1986 & $M$ & $\mathrm{P}$ & 0 \\
\hline Nuuk & 64022 & 27 June 2007 & $M$ & $P$ & 276 \\
\hline Nuuk & 64019 & 13 July 2007 & $M$ & $P$ & 302 \\
\hline Nuuk & 64018 & 27 June 2007 & $M$ & $P$ & 217 \\
\hline Nuuk & 64016 & 2 July 2007 & & & 0 \\
\hline Nuuk & 64015 & 13 July 2007 & $M$ & $P$ & 62 \\
\hline \multicolumn{6}{|l|}{ South } \\
\hline Paamiut & 62018 & 26 July 2007 & $\mathrm{H}$ & $P$ & 437 \\
\hline Paamiut & 62010 & 22 July 2007 & $\mathrm{H}$ & $\mathrm{N}$ & 0 \\
\hline Paamiut & 62003 & 22 July 2007 & $\mathrm{H}$ & $\mathrm{N}$ & 41 \\
\hline Paamiut & 62001 & 26 July 2007 & $\mathrm{H}$ & $P$ & 0 \\
\hline Paamiut & 61028 & 26 July 2003 & $\mathrm{H}$ & $\mathrm{N}$ & 0 \\
\hline Paamiut & 61009 & 26 July 2007 & $\mathrm{H}$ & $P$ & 697 \\
\hline Paamiut & 61007 & July 2003 & $M$ & $P$ & 0 \\
\hline Paamiut & 61002 & 26 July 2003 & $M$ & $\mathrm{~N}$ & 2120 \\
\hline Qaqortoq & 60087 & 28 July 2003 & M & $\mathrm{N}$ & 81 \\
\hline Qaqortoq & 60016 & 28 July 2003 & $M$ & $\mathrm{~N}$ & 95 \\
\hline Qaqortoq & 60012 & 1 August 1999 & $M$ & $\mathrm{~N}$ & 12 \\
\hline Narsaq & 61040 & 28 July 2003 & M & $\mathrm{N}$ & 33 \\
\hline Narsaq & 61039 & 28 July 2003 & $M$ & $\mathrm{~N}$ & 22 \\
\hline Narsaq & 61038 & 28 July 2003 & M & $\mathrm{N}$ & 110 \\
\hline Narsaq & 61010 & 28 July 2003 & $\mathrm{~L}$ & & 0 \\
\hline Narsaq & 60015 & 28 July 2003 & $M$ & $\mathrm{~N}$ & 134 \\
\hline Nanortalik & 60044 & 16 July 2003 & $\mathrm{H}$ & $\mathrm{N}$ & 32 \\
\hline Nanortalik & 60028 & 16 July 2003 & $\mathrm{H}$ & $\mathrm{N}$ & 3 \\
\hline Nanortalik & 60027 & 16 July 2003 & $\mathrm{H}$ & $\mathrm{N}$ & 25 \\
\hline Nanortalik & 60001 & 18 July 2003 & $\mathrm{H}$ & $\mathrm{N}$ & 5 \\
\hline \multicolumn{6}{|l|}{ North-east } \\
\hline Mallemukfjeld & 80501 & July 1993 & $\mathrm{H}$ & $\mathrm{N}$ & 873 \\
\hline Fugleø & 76528 & 16 August 2003 & $L$ & I & 7 \\
\hline Rødeø & 76524 & 16 August 2003 & $\mathrm{~L}$ & I & 5 \\
\hline Maroussia & 76508 & 29 July 2008 & $\mathrm{~L}$ & $\mathrm{~N}$ & 50 \\
\hline Hvalros $\varnothing$ & 74512 & 24 July 2008 & $\mathrm{H}$ & $\mathrm{N}$ & 75 \\
\hline Hvalros $\varnothing$ & 74511 & 24 July 2008 & $\mathrm{H}$ & $\mathrm{N}$ & 30 \\
\hline Hvalros $\varnothing$ & 74502 & 24 July 2008 & $M$ & $\mathrm{~N}$ & 40 \\
\hline Kangikajik & 70508 & 9 July 2004 & $\mathrm{H}$ & $\mathrm{N}$ & 1300 \\
\hline Immikkeertikajik & 70507 & 23 July 2004 & $\mathrm{H}$ & $\mathrm{N}$ & 600 \\
\hline Appalik & 70505 & 23 July 2004 & $\mathrm{H}$ & $\mathrm{N}$ & 450 \\
\hline Sulussuutikajik & 69503 & 26 July 2008 & $L$ & $\mathrm{~N}$ & 50 \\
\hline Dunholm & 69502 & 26 July 2008 & $\mathrm{H}$ & $\mathrm{N}$ & 57 \\
\hline \multicolumn{6}{|l|}{ Southeast } \\
\hline Umiivik & 64501 & 18 July 1933 & & & Small colony \\
\hline Taateraat & 61501 & 18 June 2008 & M & I & 97 \\
\hline West of Kap Discard & 60502 & 16 June 2008 & $M$ & I & 39 \\
\hline Kangerlussuatsiaq & 60501 & 1 June 2008 & $\mathrm{~L}$ & & 0 \\
\hline
\end{tabular}

${ }^{a} \mathrm{~L}$, low; M, medium; $\mathrm{H}$, high.

${ }^{\mathrm{b}}$ The original unit for which the count number was given. I, individual; N, nest; P, pair.

${ }^{\mathrm{c}}$ Number of individuals were converted to number of breeding pairs using a factor of 0.65 . 